\title{
Pragmastylistic Naming and Describing in Two Cameroonian Plays: What God Has Put Asunder by Victor Epie'ngome and Family Saga by Bole Butake
}

\author{
SEINO Evangeline Agwa Fomukong \\ Higher Teacher Training College (HTTC), The University of Bamenda, P.O. Box 39, Bambili - Bamenda, Cameroon \\ Email: seinoeva2014@yahoo.com
}

Received: 04-01-2017

Published: 01-09-2017
Accepted: 15-04-2017

doi:10.7575/aiac.ijalel.v.6n.5p.11
Advance Access Published: July 2017

URL: http://dx.doi.org/10.7575/aiac.ijalel.v.6n.5p.11

\begin{abstract}
In pragmatics, language is understood in context, taking into consideration the speaker, the addressee, their interaction, background information and the situation of communication. Therefore the speakers make utterances taking account of the context of communication and the cognitive environment between them and the audience. The perspective of the Relevance Theory is that the speaker gives a clue to the audience on their intention which will help the audience infer into the message with the consideration of the context. This study is based on the assumption that in naming and describing in two Cameroonian plays, What God has Put Asunder by Victor Epie'Ngome and Family Saga by Bole Butake, the intention of the playwrights go beyond what is literally communicated. The plays can only be interpreted with contextual knowledge and historical clues that tell the story of Southern Cameroons from colonisation to the present. Cameroon is a country that was colonised by both Britain and France and today is bilingual with both English and French as official languages. Britain colonised just a small portion, so out of the 10 Regions of the country only 2 Regions, North West and South West, are English Speaking. Epie'Ngome and Butake are English speaking Cameroonians and in their plays protest against the marginalisation of Anglophones by the Francophone dominated government in Cameroon. The study uncovers data from the plays, revealing historical connection of the plays to Cameroon, especially issues related to the Anglophone Problem.
\end{abstract}

Keywords: pragmatics, inference, context, relevance, linguistic sign, Cameroon

\section{Introduction}

A real work of literature is one rich in the complex relationship between man, nature and history. This relation embodies and reveals what is most typical about a particular phase in history. Amuta (1989, pp.54) says that what distinguishes each generation from the other is the nature and intensity of political challenges which it has to grapple with and recreate in its art. Therefore, significant works of arts in the contemporary African society issue firm and ideological conception of the world. Authors of these works educate the masses or the oppressed for critical consciousness not just by raising a catalogue of social ills but sensitising the oppressed of the problems plaguing them, and propose ways of combating or redressing these problems. The challenge which the national question in Africa raises has to do with the general relationship between history and literature. History and social experience furnish the context in which writers have been working especially in the post-colonial period that has been characterised by the African writer's conception which is contrary to that of the politician. The African question in African literature becomes even more pronounced in the works which are created well into the post-colonial period and in which settings, characters, and situations bear an unmistakable national identity. These works exhibit a reflection to the extent that the African readers can, through a thorough analysis, and placing the creative work, history and real social experience together, recognize familiar people, places, things and events in their real national world. This reflection comes through linguistic signals used by the authors.

Merrell edited by Paul Cobley (2001, pp. 28) argues that the Peircean sign has been defined as something else for someone in some respect or capacity. According to Chandler (2007,pp.1) the sign does not only include road signs, pub signs and star signs or visual signs but words, sounds and body language. This includes anything-from pictures, words, signals, microscopes, which stands for something else. Charles Sanders Peirce's theory of signs is a theory which asserts that all modes of thinking depend on the use of signs. He argues that every thought is a sign, and that every act of reasoning consists of the interpretation of signs. Signs therefore function as mediators between the external world of objects and the internal world of ideas and may be mental representations of objects. The whole purpose of the sign is that it should be interpreted by another sign and lies in the special character which it impacts on its interpretant (the sense made of the sign and an object to which the sign refers). According to Peirce, an instance of signification contains a sign, an object and an interpretant (Liszka 1996, pp. 18-19). The object determines the sign by placing constraints which any sign must meet if it is to signify the object. Consequently, the sign signifies its object only in the virtue of 
some of its features. Ferdenand de Saussure (Chandler 2007, pp. 2) looks at the linguistic sign as a dyadic, composed of the signifier and the signified. He considers them as nonmaterial because according to him, language itself is a form and not a substance (pp.26). He justifies this with the argument that language is arbitrary. Arbitrariness as Crystal (2001, pp. 31) defines it, is a property of human language whereby linguistic forms are said to lack any physical correspondence with the entities in the world to which they refer.

The materiality of the linguistic sign has been reclaimed by subsequent theorists like Voloshinou in Chandler (2002, pp. 2) who says all signs including language have concrete material reality. Louis Hjelmslev in Chandler (2007, pp. 30) supports the materialism of the linguistic sign by giving a framework in which he allows analysts to analyse texts according to their various dimensions and to grant to each of these the potential for signification. Like Hjelmslev, Mbangwana (2002, pp. 16) is for the view that language reflects and embodies reality and goes ahead to bring out the views of Smith and Williamson who believe in the magical power of language and as such, assert that words have a reality, an inherent meaning and power when they say 'we use words as if they were the thing,' meaning words incarnate reality for their interlocutors and users. These modern theorists who deny the Saussurian distinction between the signifier and the signified, and advocate for the materiality of language, look for meaning not in the individual signs but in their contexts and the framework of potential meanings that could be applied. Such theories assert that language is a collective memory or cultural heritage of all the different ways in which meaning has been communicated and may, to that extent be constitutive of life's experiences. This concludes that the ultimate foundation of meaning is not found in arbitrary conventions but in the rectifiable process of interpretation as in pragmatics, which deals with the interpretation of linguistic signs in contexts. Pragmatic analysis brings together language, the users and the context. This means the author's contextual experience, the purpose for communicating and the social constraints determine the text and should be considered when analysing. Leech (1983, pp. 1) argues that language users will understand the nature of language only when they understand pragmatics as, how language is used in communication. Leech (pp.14) goes on to explain that pragmatics deals with verbal acts of performances which take place in particular situations, in time. Mey (2003, pp, 6) posits that pragmatics, studies the use of language in human communication as determined by the conditions of the society. And according to C.W. Morris in Chandler (2007, pp.2) pragmatics is the relation of signs to interpreters. Pragmatics studies how words can be interpreted in different ways based on the situation, that is, pragmatics outlines the study of meaning in the interactional context taking cognizance of the physical, epistemic, linguistic and social contexts. It looks beyond the literal meaning of an utterance and considers how meaning is constructed as well as focusing on implied meaning. The implied meaning comes with implicature which denotes the act of both meaning, and implying one thing by saying something else, and can be part of sentence meaning or dependent on the conversational context (Implicature, Stadford, 2014). This pragmatic notion is explicit in the relevance theory, and in this study, can be seen in the style the authors use in naming in their plays. Naming helps the readers and hearers to understand how and why certain texts affect readers, revealing how writers use language in significant ways especially when they are studied in context. In a pragmastylistic study, therefore, the context and text are taken into consideration. The text in this case as Chandler (2007, pp. 3) describes it, 'is an assemblage of signs (such as words, image, sounds and / or gestures) constructed (and interpreted) with reference to the conventions associated with a genre and in a particular medium of communication.'

In this study that examines two Anglophone Cameroonian plays, What God Has Put Asunder by Victor Epie'Ngome and Family Saga by Bole Butake, the authors make use of implicatures. Epie'Ngome tells his story about an orphan girl who has two suitors but is tricked into marrying one who is a polygamist and whose intention is to exploit her inheritance. Butake tells his own story about two brothers living in an estate, with one suppressing the other and his children. Both authors imply the story of Southern Cameroons from colonisation, through independence to post colonisation. The authors make use of naming and describing to help the audience infer into their intended meanings. The names given to the people, places, things and events in these plays are lexical items that lead the readers to the intended meaning of the authors.

\section{Background to the study}

Cameroon was first annexed by the Germans in 1884 and later on Germany was defeated by France and Britain during the First World War, leading to the partition of Cameroon by France and Britain, in 1916. In 1960 the French part of Cameroon gained independence as La Republique du Cameroun and in 1961 the British part (Southern Cameroons) gained independence by joining La Republique du Cameroun. The Federal Republic of Cameroon was formed with two states, East Cameroon (La Republique du Cameroun) and West Cameroon (Southern Cameroons or British Cameroon), and both French and English were adopted as official languages in the country. In 1972 the President, Ahmadou Ahidjo organised a referendum in which Cameroonians voted to become a unitary state, and Cameroon was named, the United Republic of Cameroon. In 1984 the new President, Paul Biya, changed the name to the Republic of Cameroon, which is what obtains today. Presently, Cameroon is made up of the Francophones (who make up 8 Regions), those colonised by the French and the Anglophones (who make up 2 Regions, North West and South West), those colonised by the British. Cameroon therefore has two distinct cultural and linguistic backgrounds, English and French.

The Anglophones have not been comfortable with the Anglophone/ Francophone relationship in Cameroon because they feel cheated, thus the term 'Anglophone problem.' The Anglophone problem had been previewed by many as early as the institution of the federation of the two Cameroons which was at reunification in 1961. These groups and individuals of Anglophone origin started complaining when the manifestations of marginalisation became obvious. The protest against the Francophone domination of Anglophones has been done through writing, of articles in newspapers, 
novel, plays, poems, individual complaints of marginalisation, sit-in strikes and outright protests that has led to confrontations with the police and the military. Dr. Bernard Nsokika Fonlon (late), a University Lecturer at the then University of Yaoundé, and of Anglophone origin, was one of the first who previewed this usurpation of the Anglophone culture after reunification. Nkwain (2008, pp.75) states that Fonlon, in an article titled Will we make or mar, written in 1963 argues that in West Cameroon the system of driving changed from the right to the left as in La Republique du Cameroun, the Franc replaced the Sterling as legal tender, and the school year was streamlined to fit that of the East. He went on to say that by the very nature of things and by the force of circumstances, therefore, the tide was already running hard against Anglo-Saxon influence in the Federal Republic of Cameroon. Fonlon foresaw that in a few decades the culture of the Anglophones will be subsumed in that of the Francophones.

The Anglophones felt the pinch of marginalisation and started venting their grievances with the legalisation regarding political parties and social organisations during the early 90s. With the preview by Fonlon becoming visible, the Anglophones decided to come together in different ways, one of which was the All Anglophone Conference (AAC 1) held in Buea (South West Region) on 2 and 3 April 1993, called the Buea Declaration. In this conference, they adopted a common Anglophone stand on the constitutional reforms and other issues related to the welfare of the Anglophones. They complained that after the plebiscite of 11 February 1961 forming a federation between the two Cameroons, there was no valid constitutional or other legal basis that has ever existed for the unification of the two Cameroons, making the unitary form of government illegal (Buea Declaration1993, pp. 12-13). They accused the Francophone led government of economic exploitation of Southern Cameroons territory and the maginalisation of Southern Cameroonians. They also raised the argument that Anglophones only play second fiddle to Francophones as they are appointed mainly to subordinate positions to assist Francophones, even where the latter have been less qualified or less competent (pp. 18). They complained of discrimination in education and training, and the international isolation of Anglophone Cameroon. Their resolution was calling for a restoration of a federal constitution and a federal form of government which will take cognizance of the bicultural nature of Cameroon ( $\mathrm{pp}, 28)$. In addition to the Buea Declaration, there was a proliferation of Anglophone owned newspapers like The Post, The Herald, Cameroon Post, The Headlines and Social Democrat that brought out grievances against the government and helped in educating the deprived. Many Anglophones became bold enough to send articles to these papers for publication. Over Cameroon Radio and Television (CRTV), there were programmes like 'Minute by minute and Cameroon Calling, which helped to bring out and even criticise the wrongs of the government and ensure equal rights and opportunities to all Cameroonians. In this trail, Anglophone writers like Bate Besong, Bole Butake, Victor Epie'Ngome, John Nkemngong, and others seized the golden opportunity and joined their efforts to express dissatisfaction with the system in place. They joined the other institutions in clamouring for a Cameroon where there will be freedom, justice, and equality, and a Cameroon in which the Anglophone and Francophone will live in harmony.

The most recent has been the strike by the Lawyers and the teachers. The lawyers in the Anglophone Regions began an indefinite sit-in strike on 11 October 2016, demanding a return to the federal system of government, a common law legal system for the Anglophones, and the use of English Language as the sole working language in Anglophone Cameroon (North West and South West Regions). They also asked the government to redeploy Francophone magistrates from Anglophone Regions. These magistrates cannot express themselves in English and so expect the court sessions to hold in French. They are also protesting against government's call on English Common Law to be wiped out from the university system. The teachers joined the lawyers from 21 November 2016 asking for the reconsideration of the educational system, especially concerning the admission of students into the Higher Teacher Training College, and the Higher Technical Teacher Training Colleges in Bamenda and Kumba, all of Anglophone Regions. They also demanded that entry requirements into these institutions should be English certificates, the General Certificate of Education, Ordinary and Advanced Levels, and not the French equivalence, Brevet d'Etudes du Primier Cycle (BEPC) and Baccalaureate, respectively. The parliamentarians of the most prominent and powerful opposition party in the country, Social Democratic Front (SDF), carried out a protest march on 28 November 2016, reiterating the fact that there is an Anglophone problem and federalism is the sustainable solution. They made it clear that the Anglophone distinct culture must be respected, making the government and Francophone Cameroonians know, Anglophones are not a tribal or an ethnic group. The parliamentarians were clear on their stand, supporting the lawyers and the teachers. Since 11 October 2016 there has been no court sessions in the North West and South West Regions, and no schools (primary, secondary and tertiary levels) operating from 21 November in these Anglophone Regions. These strikes are indefinite, that is, until the government will solve the problems. Many individuals also came up leading the masses in protest marches in the two regions.

\section{The problem}

Considering reasons for the strikes in the Anglophone regions in October, November and December 2016, Anglophones believe that if the federal system of government continued or if they had had independence by standing on their own, they would have been better off. This is why the more radical Anglophones clamour for separation while others are fighting for a federal system of government. The Anglophones have been alienated from their culture and traditions, and have to fight back to regain what they believe is paradise lost. With these, they hope to regain their status, economic development, and political stability as was the case before Cameroon became a unitary state. This research work is motivated by the political activities from the time these works were written to what is happening today in Cameroon. The protests of today has led to the revisiting of these works (What God Has Put Asunder published in 1992 and Family Saga published in 2005) which have political implications in the lives of Anglophone Cameroonians. These works tie with a certain wind of change that was blowing across Africa in general and Cameroon in particular, during the periods 
when the plays were written and still continues today in Cameroon. Since language is a medium through which deals are negotiated, through which rebellion is planned and through which peace can be attained, these writers express their disgruntlement through writing. It is in this light that this study discusses the pragmastylistic use of naming and describing in the works of two contemporary Anglophone Cameroon playwrights: Victor Epie'Ngome and Bole Butake. The study examines the ways these authors name people, places and events, giving a clue to the readers to infer into their style of naming and get their intention of protest against the powers that be, and by so doing, proposing solutions to the Anglophone problem.

\section{Related literature}

Many critics especially of Anglophone Cameroon Literature have been writing on these plays and the Anglophone problem, since it has been an ongoing issue. Bobda (2001) argues that Anglophones started reacting in all kinds of ways after co-existing with their Francophone countrymen. The reason being that Anglophones are faced with what they consider accumulated injustice perpetrated against their language, themselves and their culture. He continues to explain that Anglophone pressure groups have continued to strengthen and evolve from demanding a return to the federated state, having equal rights with the Francophone state, as after the 1961 plebiscite, to an outright independence of Southern Cameroons.

Takem (2002) takes a more literary view, looking at the Anglophone Cameroon theatre from the politics of Nation building. Takem portrays the Cameroonian situation as French-speaking and English-speaking communities cohabiting. He explains that the official discourse, ranks the country as a success story in nation building but argues that the reality, however, is that since the early 1990s, Anglophones have been agitating for secession of their community from the political union with their French-speaking compatriots. In his analysis of What God Has Put Asunder, Takem portrays that Epie'Ngome rejects the assertion that Cameroon is a progressive nation at peace with its two principal communities. He explains that the name Weka is formed from a collapsing of West and Kamerun (German version of Cameroon), and stands for West Cameroon or English-speaking Cameroon.

Ambanasom (2007) describes What God Has Put Asunder as a play having a greater symbolic significance in the Cameroonian context. He gives an example of the marriage metaphor which relates to the political union of Anglophone Cameroon and its Francophone counterpart. Hence, Weka stands for the former Southern Cameroons and Garba for La Republique du Cameroun. Accordingly, Weka's parents represent the British government that relinquished responsibility over Southern Cameroons. Ambanasom concludes that the ultimate social relevance of What God Has Put Asunder is to educate the Anglophone Cameroonians.

In analysing of Family Saga, Odhiambo (2011) elaborates on Butake's vision and ideology of change in Butake's previous works. He brings to view the similarities of Butake's postcolonial society with that of other postcolonial writers in which there is underlying revelations of anxieties and tensions. Odhiambo describes the relationship between Kamala and Kamalo as two brothers in the play that symbolize the Anglophone and Francophone linguistic dichotomy. Therefore the conflict in Kamalo oppressing Kamala is that of the Francophone oppressing the Anglophone in the real Cameroonian context. He examines instances in which Kamalo is portrayed performing power over the oppressed like the rape of Sawa, the detention of Kamala and the dispossession of his family. He concludes that in this work Butake targets the conscience of the oppressor. This very notion is expressed by Pangmeshi (2013, pp. 116) who argues that Butake's metaphorical focus is the relationship between the Francophone Cameroon (East) and the Anglophone Cameroon (West). He examines the conflict in state provision between Kamala and Kamalo and concludes that 'nation and nationhood in postcolonial Africa is unequivocally paradoxical and controversial due to the fact that those who wield power have without any shame become dictators, tribalistic and have employed all forms of exploitative means to further colonize their citizens' (120).

Many have written on the Anglophone problem in Cameroon, on What God Has Put Together and Family Saga with focus on literary analysis. But this study examines the language in literature with focus on pragmastylistic naming of people, places and events, that is, analysing from a linguistic perspective. The analysis will follow a descriptive method used to describe, define, explain and clarify the names used, in relation to the circumstances surrounding the name, and in conjunction with the history of Cameroon.

\section{Authors' biography}

\subsection{Victor Epie'ngome}

Victor Epie'Ngome was born on 10 October 1947 in Muabi, a village on the western slope of the Muanenguba Mountains, in the South West Region of Cameroon. He did his primary education in the Ava Maria School Bangem and secondary education in St Joseph's College Sasse (Buea). He later read agriculture in Cameroon College of Arts, Science and Technology (CCAST) Bambili while privately doing the General Certificate of Education (GCE) Advanced Level in French, Fine Art and English. He worked with the West Cameroon Department of Agriculture from 1970 and in 1976 he resigned to start a career in journalism. To pursue this, he studied in the Advanced School of Mass Communication (ASMAC) in Yaoundé, the University of Western Ontario in Canada and Michigan State University. He also studied bilingual studies (Linguistic major) at the University of Yaoundé, Faculty of Letters and Social Sciences (Epie'Ngome, 2003). With his charisma in journalism, Epie'Ngome worked for at least eight years as a broadcaster for Cameroon Radio and Television (CRTV). While there, he held positions including Deputy Editor in Chief (Radio), Broadcast Supervisor (TV) and Head of English Language programmes. He also worked as BBC 
correspondent for 16 years, and for two years as Reuters News Agency stringed, with stints as reporter for Concord, West Africa and Focus on Africa magazines and as Desk Editor for the Herald Newspaper.

He started writing as early as 20 when he produced his first play Musima my son. His unpublished works include a novel-the Backslider and a number of plays-Not yet the Name, The First Defence. He also has The people versus Madiba, Hot Pepper Soup, Havoc in the Harem, The Pigeon and the Gecko and The Pastor's Ram. Epie'Ngome's age permits him to have lived in the time of Southern Cameroons, West Cameroon, The Federal Republic of Cameroon, United Republic of Cameroon and Republic of Cameroon. He's an eye witness who has a lot to dish out through his plays to educate the Anglophones on their plight.

\subsection{Bole Butake}

Bole Butake (late) was from Nkor Noni which is a minority to Oku and Nso, in the Bui Division, North West Region of Cameroon. He was born in July 1948. He had the GCE Ordinary Level from Sacred Heart Mankon and the Advanced Level from Cameroon College of Arts, Science and Technology (CCAST) Bambili. He got his Bachelor of Arts in English studies and proceeded to the University of Leeds where he had his Masters in English Literature. He defended his doctoral thesis in 1983 in the University of Yaoundé (Butake, 1992, pp. 20). He taught at the Bishop Rogan College, Buea and worked with the West Cameroon Department of Lands and Surveys. Butake was a Professor in the Department of Arts and Archaeology in the University of Yaoundé 1 and was the Vice Dean in Charge of Academic Affairs in the Faculty of Arts, Letters and Social Sciences, University of Yaoundé 1. Before his death in October 2016, he was the Dean of the Faculty of Arts and Social and Managerial Sciences at Cameroon Christian University, Bali, North West Region. He was a playwright, essayist, critic and activist. Some of his plays include: The Rape of Michelle, Lake God, And Palm-Wine Will Flow, The Survivors, Shoes and Four Men in Arms, Dance of the Vampire, Marriage without Betrothal, and Family Saga.

\section{Summary of the works to be discussed}

The works to be discussed are What God Has Put Asunder by Victor Epie'Ngome published in 1992 and Family Saga by Bole Butake published in 2005.

\subsection{What God Has Put Asunder}

What God has Put Asunder is a play by Epie'Ngome about an orphan girl, Weka, who grows up in an orphanage headed by Reverend Gordon and Sister Sabeth. These two coerce Weka to get married to Garba who is also from the Njanga clan as Weka, but grows up in a different orphanage headed by Louis. The marriage is countered by Emeka who grows up in the same orphanage as Weka but is from the Delta clan. Weka is not happy about the marriage, so at the wedding instead of accepting Garba as her husband, when asked, she remains silent and later bursts into crying. She complains she does not even know Garba and cannot trust him. With the reluctance of Weka to give her consent to the marriage and the fact that Garba takes exceptions to certain portions of the marriage vow that he cannot obey a woman, the marriage is solemnised probationally by withholding the rings. Reverend Unor concludes that the ring shall be put only after ten years, and only if they desire to continue living as a couple.

Weka goes with Garba as stated in church and later on discovers that Garba is a polygamist and flirts with Fatou, his driver's wife. She plans with Sani, Fatou's husband to go out to the theatre and at the end of the play Weka and Sani meet with Fatou and Garba. After some insulting exchanges between Weka and Garba, she packs out of Garba's house and decides to go back and rehabilitate her late father's house and cocoa farms. The couple end up in court and the judge rules that the two parties shall continue to live in physical separation.

\subsection{Family Saga}

Family Saga is a play written by Bole Butake that tells a story of two brothers, Kamalo and Kamala, living in an estate. Kamalo is rich, 'tall and fat wearing a three piece suit'(Butake 2005, pp.6), and as the play opens he is lounging in an easy chair drinking and smoking and listening to a Bikutsi tune which is very loud. Contrastingly, Kamala is a diminutive man in a workaday jumper, and given the position of the executor while Kamalo is the conceiver. This means Kamalo sits in the office, takes decisions and gives orders for Kamala to carry out on the fields. He tells Kamala, 'I conceive, and you execute. Period.' Kamala has two children, Ngong and Sawa, who work on the fields with him while Redone, Kamalo's son, is there on the fields with a gun, drinking whisky and watching them work. Kamalo boasts of his Papa so much so that Kamala goes in search of his own father, Baakingoom, who does not even want to listen to Kamala's complaint of being oppressed by Kamalo. While Kamala is away to see Baakingoom, Kamalo rapes Sawa. In a play to entertain Kamalo out in the fields, Kamala, Ngong and Sawa act the rape of Kamanda. In this play the story teller recounts the history of the two brothers, Kamalo and Kamala. Their mother Kamanda is raped by Yaman, Baakingoom and Fiekafhim. This comes about when Kamanda sends for Baakingoom but the messenger instead calls for Yaman who comes and rapes her. Yaman boasts of his manhood and when Baakingoom discovers that he was the one sent for, Baakingoom conspires with Fiekafhim to eliminate Yaman. At the time they are reporting this to Kamanda she has already lost her mind and cannot even make the difference. Baakingoom and Fiekafhim take advantage of Kamanda's madness and rape her. She becomes pregnant and both of them claim responsibility. She gives birth to twins, naming one Kamalo, meaning the big one, and the other Kamala, meaning the small one. Baakingoom and Fiekafhim forcefully take the children, Baakingoom claiming the small one and Fiekafhim taking the big one. Fiekafhim goes ahead to seize Kamanda whom he locks away so as to better exploit Kamalo and the wealth of his people, especially his brother Kamala and his two children, Ngong and Sawa. The play-within-a-play is so touching that Kamalo sees himself as Kamala's brother thereby regretting the rape of Sawa. The play ends with Kamalo apologizing 
to Kamala and his family promising that 'we shall all conceive and execute, each according to his ability' (Butake 2005, pp.84). There is understanding and equal rights in the estate.

\section{Theoretical framework}

This study bases on the theory of Relevance by Deirdre Wilson and Dan Sperber. Wilson and Sperber (2004, pp.608) argue that the central claim of the Relevance theory is that expectations of relevance raised by an utterance are precise enough and predictable enough to guide the hearer towards the speaker's meaning. They go on to explain that an input (a sight, a sound, an utterance, a memory) is relevant to an individual when it connects with the background information he has available and when its processing in a context of availability yields a positive cognitive effect. This comes from the input and context together. Relevance theory ascertains that the greater the positive cognitive effects achieved by processing an input, the greater its relevance will be. The input therefore, has to have an interpretable connection with the context.

Wilson and Sperber discuss the human cognitive system and its functions in the Relevance Theory. They explain that as a result of constant selection pressure towards increasing efficiency, the human cognitive system has developed in such a way that the perceptual mechanisms tend automatically to pick out potentially relevant stimuli, the memory retrieval mechanisms tend automatically to activate potentially relevant assumptions, and the inferential mechanisms tend spontaneously to process them in the most productive way. Therefore the speaker produces a stimulus that attracts the attention of the hearer and prompts the hearer to retrieve certain contextual assumptions and to point towards an intended conclusion. The use of sight, sound, words, utterances and memory is not just a matter of intending to affect the thoughts of an audience, it is a matter of getting them to recognise that the speaker has this intention. Consequently, the speaker uses ostensive-inferential communication which involves the use of an ostensive stimulus, designed to attract an audience's attention and focus it on the communicator's meaning.

The ostensive stimulus raised by Epie'Ngome and Bole Butake in their plays in naming of people events and things attract the attention of their readers. The names given can be retrieved from certain contextual assumptions, events that happen in Cameroon and the people around whom these events rotate. This naming is relevant to the readers because they connect with background information to productively get to an intended conclusion.

\section{Results and discussions}

This section discusses the naming and describing in What God Has Put Asunder and Family Saga. The naming of people, places and events in these plays together with the history and present day happenings in Cameroon, is very relevant to the interpretation of the plays. The authors coin the names to suit their purpose and help the audience through these names, that is, what the characters say, do and what is said about them, to understand their intentions.

\subsection{Naming And Describing In What God Has Put Asunder}

'What God has put together, no man should put asunder,' comes from the liturgy of the Presbyterian Church in Cameroon used when solemnising marriages. Epie'Ngome is talking about a marriage that cannot work so he uses the title, What God has Put Asunder. If it were to be completed it will read 'let no man put together.' The play is all about proving that the marriage between Garba and Weka cannot work. Firstly, they go in for monogamy, meanwhile Garba has other wives. Secondly, they grow up in different orphanages with very different upbringings. Through Weka the readers are exposed to the different upbringings. She explains this to Emeka.

Weka: I had wanted to be on my own when I had to leave the orphanage twenty years ago. What more now that we are a family?

Emeka: Yes that's what Reverend Gordon used to call self-reliance (39).

Weka goes on to describe Garba's upbringing.

Weka: And Louis taught Garba to feel like a member of his own family.

To this day, even as an old polygamist and father of a brood of brats, Garba does nothing without asking Louis first. Would you believe, for instance, that Garba lets Louis keep his money for him and cannot buy anything without Louis' blessing? (40).

This goes back to the policy of assimilation, what Weka means 'feel like a member of his own family' used by the French (represented by Louis in the play) and the policy of indirect rule what Emeka calls 'self-reliance' used by the British in Southern Cameroons as a method of ruling. This is a satire on the French colonial policy of assimilation and neo-colonialism meddling in Cameroonian affairs. The French assimilation policy during the colonial period made the colonised people to feel like French people. Through these ostensive stimulus, Epie'Ngome gives a clue of the assumption to be made and his audience come out with his intentions making them see his protest against what is happening in Cameroon between the Francophone dominated government and the Anglophone minority.

\subsubsection{Austin Ngom}

In the play-within-a-play, John the Baptist acted by Austin Ngom, is beheaded because he dares point out Herod's injustice toward his brother. In the Cameroonian context Augustine Ngom Jua was a famous politician from the North 
West Region of Cameroon who was not afraid of the former President of Cameroon, Ahmadou Ahidjo, and many freedom fighters hail Augustine Ngom Jua for his brevity and openness, his fight for liberation. Many writers and freedom fighters use him as an example to tell the masses that a hero must not only fight but show relentless efforts to fight for his rights, freedom and equality. Augustine Ngom Jua led the Anglophone politicians to insist on the respect of the Foumban accord in which the Anglophones' minority rights were safeguarded (Ambanasom, 2002, pp. 20). The boldness of Austine Ngom in the play is the same boldness of Augustine Ngom Jua in the political arena of Cameroon. The resemblance in name is seen in their actions, guiding the audience to create the link between the two.

\subsubsection{Weka}

Weka is brought up in an orphanage controlled by Reverend Gordon and Sister Sabeth. Weka is well brought up and Reverend Gordon testifies to this. He says that they 'are the most aggrieved to have to part which such model of Christian womanhood from these precincts' (Epie'Ngome, 1992, pp.9). She easily loses her temper especially when Sister Sabeth and Reverend Gordon talk to her about suitors who come to seek her hand in marriage. These suitors are Garba and Emeka. Weka is forced to get married to Garba and since she cannot stand Garba's excesses, asks a lot of questions to Garba and tells him to his face that if his other wives do not ask questions, 'I was brought up to ask questions about everything I don't understand' (pp.33). She accuses Garba of harvesting from her farms without even pruning the trees, weeding the farms or clearing the road thereto. Weka fights her way through and successfully gets separation. This is an allusion to colonial and neo-colonial British and French influences on Cameroon. Weka stands for West Cameroon. 'We' stands for West and 'Ka' for kamerun (spelling for Cameroon during German annexation). Weka's complaints are suggestive of the complaints made by the Anglophones against the Francophone dominated government in Cameroon. Her marriage to Garba suggests the union between La Republique du Cameroun and Southern Cameroons in 1961 that is considered a union which cannot work because of the distinct cultural differences. Carrying out a rehabilitation of her abandoned property is a proposal for the Southern Cameroonians to carry out rehabilitation when they will once more become a federal state as proposed by Epie'Ngome at the end of the play. Weka's complaints of Garba harvesting but not pruning, is the complaints Anglophones make of the Francophone government tapping their oil, timber and other natural resources, but not maintaining the roads and repairing the structures in the Anglophone part of the country.

\subsubsection{Garba}

Garba also grows up in an orphanage where Louis is the rector. He gets married to Weka but has other wives. Garba is exploitative, extravagant and unfaithful to his wives. He gets married to Weka because of the wealth her father leaves for her. He flirts around with Fatou and lavishly spends money in the 'Satellite Hotel' that is of 'the highest standing in town' (Epie'Ngome 1992, pp.14). It is ironical that Garba's speech reads that opportunists stash away the people's hard-earned money in fabulous bank accounts in foreign lands while the masses continue to eke out their wretched existence. In his speech he asks the questions, 'How can there be peace and concord if some starve while others waste?' (pp.20). This is ironical because Garba is the one squandering the money, living it up with prostitutes in luxurious hotels. A hotel bill for four days is 300,000FCFA and according to Garba it is not bad. The cheque for this bill is not made from a private account but from the Co-operative's account. He says the Co-operative is everybody and nobody, so its losses weigh on no one in particular because they are shared by all members. Contextually, Garba is a famous name used by those in the North of Cameroon. At the time of independence and reunification the president of Cameroon President Ahmadou Ahidjo (late), hailed from the North Region of Cameroon. Garba stands for La Repubique du Cameroun, which was well established and already had independence before coming together with Southern Cameroons, the reason Weka says he already had many wives. In Cameroon today, the cry is that of government officials swindling money into huge accounts abroad and the masses are made to work for very little as in nothing.

\subsubsection{Emeka}

Emeka grows up in the same orphanage as Weka but comes from the Delta clan. He tries to get married to Weka to no avail. When Weka separates with Garba, Emeka comes, still trying to win Weka's love but does not succeed. Contextually, Emeka is a household name amongst the Ibos in Nigeria. Emeka therefore is an ostensive stimulus that leads the audience to linking him with Nigeria. This can be seen in the fact that Emeka and Weka grow up in the same orphanage. Symbolically, Nigeria and Cameroon were jointly controlled by the British. At one time Southern Cameroons was ruled as a state in Nigeria under British rule. This was before reunification, that is, when Southern Cameroons had representatives in the Eastern House of Assembly in Enugu, Nigeria. This is the reason Weka and Emeka are considered to have grown up in the same orphanage, which is Britain.

\subsubsection{Reverend Gordon, Sister Sabeth and Louis}

Reverend Gordon and Sister Sabeth stand for the colonial administrators of the British in Southern Cameroons. They are in charge of the orphanage in which Weka and Emeka grow up. Weka tells Emeka that Garba also grows up in an orphanage just like they do, and the rector of the orphanage, Louis is her foster father-in-law, in other words Garba's foster father. Contextually, at the time, orphanages were owned by the catholics, so Epie'Ngome had to use Catholic administrators who were usually reverend fathers and reverend sisters. The orphanage represents the different colonies of Britain and France. The orphanage Garba grows up in, is the French Cameroon, with France as the colonial master, while Weka and Emeka grow up in Southern Cameroons and Nigeria respectively, as British colonies. Weka tells Emeka that 'Louis taught Garba to feel like a member of his own family and Garba does nothing without asking Louis 
first.' Louis suggests France. Louis uses the policy of assimilation to control the orphans just as France uses the policy of assimilation to control its colonies, especially Cameroon.

\subsubsection{Unor}

Unor is the Reverend father who celebrates the marriage between Weka and Garba. He testifies in court that the marriage between Weka and Garba does not actually take place. Reverend Unor, in solemnising the marriage between Weka and Garba, represents the United Nations Organisation during the plebiscite it organised on 11 February 1961 in Cameroon. The ostensive stimulus is the use of ' $U$ ' for United, ' $N$ ' for Nations and 'Or' for Organisation, and the description of Unor's role in the marriage ceremony. Symbolically, the marriage between Garba and Weka is the reunification of Southern Cameroons and La Republique du Cameroon in 1961. Ambanasom (2002, pp.3) explains that the play, within the Cameroonian context is a marriage metaphor which relates to the political union between Anglophone Cameroon and their Francophone counterpart.

\subsubsection{Njanga Clan}

Sister Sabeth tells Weka that one of the suitors who comes for her hand in marriage is also from the Njanga Clan and his name is Miche Garba. Garba is said to come from the Njanga clan as Weka because Cameroon was one before the separation by the French and the British. Epie'Ngome's njanga is the Pidgin English word for prawns which through the Portuguese expression 'Rio dos Cameroes,' becomes a nickname for Cameroon (Mbangwana, 1993:61-62). What God Has Put Asunder is therefore seen to be about Cameroon's independence, reunification and the problems of nation building.

\subsection{Naming And Describing In Family Saga}

\subsubsection{Kamala and Kamalo}

Kamalo is presented as fat, wearing a three piece suit, lounging in an easy chair, drinking and smoking, and listening to Bikutsi music. His position is that of one who is rich and living a good life. He is the bigger of the twin and oppresses Kamala the smaller twin. He tells Kamala,'I conceive, you execute. Period. That's what my papa says.' He relies on his papa. Kamala on the other hand is presented as a diminutive man in a workaday jumper. Kamalo asks Kamala, 'Me? Sweep out the barn and repair the shelves for what? That your work is what?'(Butake, 2005, pp.8). Kamala tells, his father, Baakingoom about Kamalo, 'I am his slave, toiling in the fields from dawn to dusk in these rags while he is having air-conditioning at home in a three piece suit.' In Cameroon, the Bikutsi music is a culture of the Centre Region, a Francophone Region, considered as the region in power, because the President Paul Biya is from that region. Kamalo's presentation symbolises the position of the Francophones, giving orders and taking decisions as against Anglophones, who have no power in government. In the Buea Declaration (1993, pp. 18) it is termed 'marginalisation' since Anglophones play second-fiddle to their Francophone compatriots. The Anglophones also blamed the Francophone led government for their reluctance to fulfil the essential conditions for the admission of Cameroon into the Commonwealth long after Cameroon became a full member of the Francophonie (Buea Declaration 1993, pp. 26). Kamalo's rich position symbolises the Francophones who are exposed to better opportunities and Kamala represents the Anglophones who cannot make it easily to better positions, so remain poor and voiceless.

\subsubsection{Ngong and Sawa}

Ngong and Sawa are Kamala's children. Together with their father, they are being oppressed by Kamalo and work on the fields. Ngong is protective of Sawa but later on discovers that Kamalo tricks Sawa out because of her vulnerability and naivety. Kamalo lures her into his house and rapes her. After the rape of Sawa and the return of their father, together they fight Kamalo under the disguise of entertainment. In the Cameroonian context Ngong is a male name used in the Boyo and Menchum divisions of the North West Regions. Sawa is a name used to refer to the South West Region of Cameroon. Ngong and Sawa suggest the two Anglophone Regions of Cameroon. The rape of Sawa therefore is the plundering of the South West Region by the government of Cameroon. One major action cited by many who protest is the SONARA oil refinery which is in Limbe, in the South West Region but pays taxes to Douala in the Littoral Region, one of the Francophone regions in Cameroon. Kamalo tries to disassociate Sawa from her family, promising her a better life but she refuses. When Sawa is back together with her family, Kamala and Ngong, they adopt the motto, 'Unity is strength. United we stand, divided we fall' (Butake 2005, pp. 62). This can be seen in the complaints of the Anglophones during the Buea Declaration (1993, pp.17-18), when the Anglophones complained that the Francophone led government is trying to use a 'divide and rule' policy, so that the South West and the North West Region will be separated and fused with Francophone regions, a strategy to dilute and eventually wipe out the Anglophones in Cameroon.

\subsubsection{Kamanda and the Estate}

Kamanda is raped by Yaman, Baakingoom and Fiekafhim and is the mother of the twins, Kamalo and Kamala. Kamanda represents Cameroon before the coming and during the occupation of Germany, Britain and France. The significance of the rape is the fight that these three countries had over Cameroon and resulted in the colonisation of Cameroon by Britain and France. The estate is where Kamalo and Kamala live. Kamala asks Kamalo 'How many times must I remind you that there are two people living on the estate? (Butake 2005, pp.8). The estate symbolises Cameroon after the plebiscite of 11 February 1961 when the two Cameroons reunited. Through Kamanda the audience get a clue of Butake's intention. 
Yaman is the trader who first rapes Kamanda in the play-within-a-play. In telling the family story Ngong says some people encourage Kamanda to choose among the three traders struggling for her attention. Sawa says, when the people encourage Kamanda, she prefers Baakingoom, so she sends a message to Baakingoom to come at night but the messenger instead goes to Yaman because he does not know the difference between the three. Kamanda identifies Yaman, and tries to resist him but Yaman forcefully gets in and rapes her. This is the story told of Cameroon and the coming of the Germans. Bobda (2001, pp.1) explains that the Duala (presently Douala, the economic capital of Cameroon) Kings begged Queen Victoria for a long time to make their territory a British protectorate. When Hewett of Britain returned from his leave to arrange for the annexation, the message had already gone to the Germans and they annexed Cameroon. The elimination of Yaman by Baakingoom and Fiekafhim in the play suggests the defeat of Germany by the joint forces of Britain and France during the First World War. Baakingoom is one of Kamanda's suitors and the father of the smaller twin. He does not recognize Kamala when Kamala goes to him to complain about Kamalo. Baakingoom accuses Kamala for not attending the family reunion every two years even though he sends the invitation to Kamala. This is about the Commonwealth of which Cameroon was not yet a member. From what he tells Kamala, he warns Kamala not to get into union with Kamalo but Kamala would not listen. Fiekafhim is another of Kamada's suitor who takes the bigger twin, Kamalo. He is Kamalo's papa who as Kamala says 'sneak in like a thief when I am toiling in the fields to steal my provisions and disappear again' (Butake 2005, pp. 12). Kamalo confirms this when he tells Sawa 'My papa is really my papa and his hawk's eye will always spot a resource wherever it is hidden' (pp. 31). Baakingoom tells Kamala about Fiekafhim that Kamalo has 'been hypnotized by a most Machiavellian and sucking parasite, a self-styled father' (pp. 23). Fiekafhim is in control of everything Kamalo does because in everything, Kamalo says it is 'what my papa says.' Fiekafhim represents France which takes the bigger portion after the defeat of the Germans in Cameroon, which is the Francophone section of the country.

\subsubsection{Court of Deeds}

The deed signed at the Court of Deeds is considered by Kamalo as the deed of bondagehood and by Kamala as a deed of brotherhood. Kamalo tells Sawa 'We signed a deed of bondagehood. So he and all that belong to him belong to me' (Butake 2005, pp. 31). Kamalo uses this to justify his suppression of Kamala but Kamala on his part considers it a deed of brotherhood. Baakingoom does not see any difference. He tells Kamala, 'Brotherhood, bondagehood. Bondagehood, brotherhood. What is the difference? I don't Know what you chose, son. I warned you when you took freedom... You refused to listen' (pp.19). The Court of Deeds represents the United Nations Organisation that handled the issues of independence and reunification in Cameroon in 1961.

\section{Conclusion}

The two plays analysed in this study have different linguistic signals in naming of people, places and events but carry the same interpretations. Both stories are about Southern Cameroons from colonisation to postcolonisation. Epie'Ngome in What God Has Put Asunder names Anglophone Cameroon, 'Weka' and Francophone Cameroon 'Garba', while Butake in Family Saga names them 'Kamala' and 'Kamalo' respectively. Epie'Ngome tells his story from a metaphor of marriage between Garba and Weka, and portrays the colonial masters as heads of orphanages, while Butake tells his from the point of view of an estate where there are two brothers, one person is a conceiver and the other an executor, and the colonial masters are suitors. At the end of What God Has Put Asunder, the court rules that Garba and Weka live separately. Kamalo in Family Saga is not comfortable with the questions asked by Kamala and Sawa, just as Garba in What God Has Put Asunder tells Weka, her mates never questions about what he does, but Weka retorts, that she is brought up to ask questions about everything. In What God Has Put Asunder the United Nations Organisation is represented by Reverend Unor and in Family Saga, the United Nations Organisation is represented by the Court of Deeds. Epie'Ngome proposes that there be a federation and Butake sees a Cameroon where the Francophones apologize to the Anglophones and they live as one family. The common background of the plays makes interpretation easy to the audience who understand the historical and sociocultural context in which the plays are written. The names are different but the descriptions of events and circumstances surrounding the characters are connected, giving a clue for interpretation of the texts, thereby arriving at the authors' intentions.

\section{References}

Ambanasom, S. (2002). Education of the Deprived: A study of four Cameroonian Playwrights. Bamenda: Unique Printers.

(2007). Cameroon Literature in English: Celebrating the Literarary Renaissance in Anglophone Cameroon (former British Southern Cameroons). Anglocamlit,blogspot.com/2007/11/what-god-has-put-asunder-byvictor-epie.html.

Amuta, C. (1989). The theory of African Literature: Implications for Practical Criticism. London: Zed Books.

Bobda, S. (2001). Varying perception of English in Cameroon: A Diachronic and synchronic Analysis. In: Trans. Internet-Zeitschrift für kul turwissenschafter No. 11/2001. http://www.inst.at/trans/11Nr/bodda11.htm

Butake, B. (1996). The Writer as Visionary. Epasa Moto, 1(3), pp. 19-27.

(2005). Family Saga .Yaoundé: Editions Clé. 
Chandler, D. (2007). Semiotics for beginners. www.aber.ac.uk/media/documents/S4B/Semiotic.html

Epie'Ngome, V. (2003). What God Has Put Asunder. Yaoundé: Pitcher Books Ltd.

Fanso, V. (1989). Cameroon History for Secondary Schools and Colleges: The colonial and Postcolonial Periods. London: Macmillan Publishers Ltd.

Grundy, P. (1995). Doing Pragmatics. London: Hodder Headline PLC

Juan, S. E (2011). A Preface to Charles Sanders Peirce's Theory of Signs. Philippine Journal of Social Sciences and Humanities, 16 (2), pp. 49-56.

Leech, G. N. (1983). Principles of Pragmatics. London: Longman

Levinson, S.C. (2003). Pragmatics. Cambridge: CUP

Liszka,J .J. (1996). A General Introduction to Semeiotics of Charles Sanders Peirce. Indianapolis: Indiana University Press.

Mbangwana, P. (1993). The Stylistic and Artistic Comparism of Some Cameroonian Playwrights: A study of the Technique of Double Entendre. New Literature Review number 25, pp.59-66, Summer South,University of Wollongon.

Mey, J.L (2001). Pragmatics: An Introduction Oxford: Blackwell Publishers Inc.

Mukong, A.W. (1990). The case for the Southern Cameroons. N.p : CAMFECO.

Ngoh, V. J. (1996).History of Cameroon since 1800. Limbe: Presbook

Nkwain, F.I.W. (2008). Cameroon: Higher Grounds for National Unity and Peace, Bamenda: Maryland Printers.

Odhiambo, C.J. (2011). Theatre of the Oppressor:A Reading of Bole Butake's play, "Family Saga." Journal of English and Literature, 2(3), 53-59.

Pangmeshi, A. (2013). The paradox of nation and nationhood and the process of reconciliation in Bole Butake's Family Saga. International Journal of English and Literature. Vol, 4(4). Pp.115-121. DOI: 10.5897/IJEL 12.097.

SCNC, 2000. Towards a Better Understanding of the Southern Cameroons Question. Buea, No 4, 5 \& 6. (unpublised). Sperber, D. \& Wilson, D. (1995). Relevance: Communication and Cognition. Oxford: Basil Blackwell.

Stadford Encyclopedia of Philosophy (2014) Implicature. http://plato.stanford.edu/edu/entries/implicature

Takem, T. (2003): Multiculturalism and Politics of Nation Building in Recent Anglophone Theatre, www.griffith.edu.au/centre/cpci/atr/contents-journal- 2003.html

The Buea Declaration. 1993. All Anglophone Conference. Limbe: Nooremac Press

Wilson, D \& Sperber, D. (2004). Relevance Theory. In Horn, L.R \& Ward, G. (eds.) 2004. The Handbook of Pragmatics. Oxford:Blackwell, pp.607-632.

Xu, Z. \& Zhou, Y. (2013). Relevance Theory and Its Application to Advertising Interpretation. Theory and Practice in Language Studies, 3(1), pp. 492-496. 